\title{
Furosemide induced bullous pemphigoid: a case report
}

\author{
Venu D., Vijendra R.*
}

Department of Pharmacology, KIMS Bangalore, RGUHS, Karnataka, India

Received: 27 February 2019

Revised: 15 April 2019

Accepted: 03 May 2019

\section{*Correspondence to:}

Dr. Vijendra R.,

Email: vijendra_ramaiah@ yahoo.co.in

Copyright: (C) the author(s), publisher and licensee Medip Academy. This is an openaccess article distributed under the terms of the Creative Commons Attribution NonCommercial License, which permits unrestricted noncommercial use, distribution, and reproduction in any medium, provided the original work is properly cited.

\begin{abstract}
Bullous pemphigoid is an acquired autoimmune disease characterized by subepidermal vesicles and bullae. The etiology is mostly idiopathic with the highest occurrence in elderly patients. However, it is now well-accepted that bp has been triggered by or associated with drug therapy. Over 50 agents have been implicated as a cause of Drug-induced bullous pemphigoid, including diuretics, ace inhibitors, and antibiotics. We present a case of Bullous pemphigoid in a 75 year old male probably induced by furosemide. A 75 year old male was admitted to the dermatology department of KIMS hospital, Bengaluru. Presented with multiple tense bullae and vesicles over both upper limbs, forearm and few collapsed bullae and vesicles over the extensor aspect of forearm. Patient had a past history of myocardial infarction and undergone coronary artery bypass grafting for the same and treated with multiple medications. Among the treatment given injection furosemide was the one of the drug, after which he developed lesions and also presented with fluid filled bullae. A diagnosis of bullous pemphigoid was made based on clinical history and was treated with prednisolone, halobetasol and antibiotics. The lesions improved significantly with the above management and patient recovered enough to be discharged from the hospital after 5 days. Severe and serious reactions such as bullous pemphigoid can be caused by used drugs like furosemide.
\end{abstract}

Keywords: Adverse drug reaction, Bullous pemphigoid, Diuretics, Drug induced cutaneous reaction, Furosemide, Naranjo ADR Probability Scale

\section{INTRODUCTION}

Bullous pemphigoid (BP) is an acquired autoimmune disease characterized by subepidermal vesicles and bullae. The etiology for BP is mostly idiopathic with the highest occurrence in elderly patients; however, it is now wellaccepted that BP has been triggered by or associated with drug therapy. ${ }^{1}$ Over 50 agents have been implicated as a cause of Drug-induced bullous pemphigoid (DIBP), including diuretics, ACE inhibitors, and antibiotics. ${ }^{2}$ Commonly reported drugs inducing bullous pemphigoid includes NSAIDs, furosemide, penicillamine, terbinafine, captopril, spironolactone, celecoxib, serratiopeptidase, mefenamic acid, beta-blockers, psoralens, sulphonamides, Chloroquine, ciprofloxacin. ${ }^{3}$
Furosemide is a widely used medication for treatment of congestive heart failure, hypertension, and various other conditions for its diuretic action. Available in parenteral and oral forms depending on need of therapy. Furosemide is one of the important drug attributed for causation of drug induced bullous pemphigoid. ${ }^{4}$

\section{CASE REPORT}

A 75 year old male was admitted to the dermatology department of KIMS hospital, Bengaluru, presented with multiple tense bullae and vesicles over both upper limbs (Figure 1), forearm and few collapsed bullae and vesicles over the extensor aspect of lower limbs (Figure 2) and chest (Figure 3). Patient had a past history of myocardial 
infarction, undergone coronary artery bypass grafting $(\mathrm{CABG})$ for the same and treated with multiple medications in a private hospital. Among the pharmacological treatment provided injection furosemide was one of the drug.

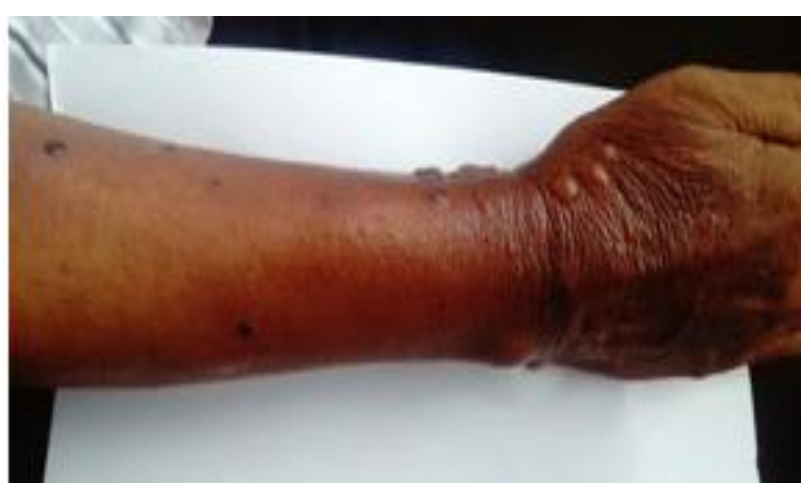

Figure 1: Bullae and vesicles over the forearm and hand.

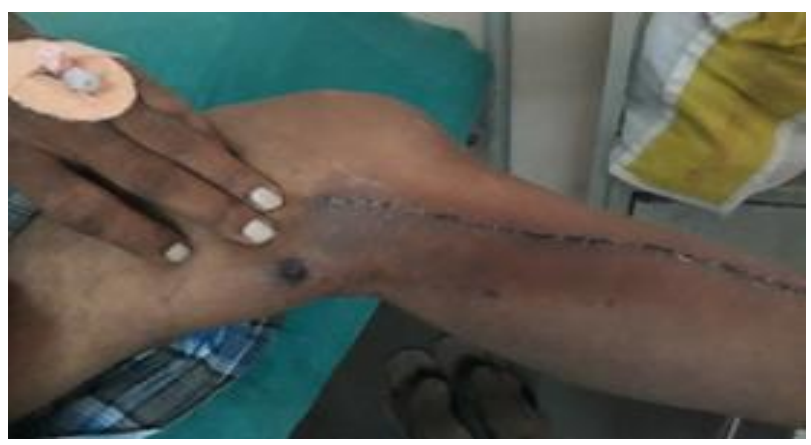

Figure 2: Collapsed bullae seen over the lower limb.
After 2 days of administration of the drug, he developed fluid filled bullae and itching. First over the chest and upper limbs extensor aspect. After that bullae were drained and anti-histamine drug was administered, then patient was discharged from hospital after 2 days with continuing the treatment for Hypertension and Ischemic heart disease. Post discharge treatment included Furosemide, aspirin, bisoprolol, silodosin, ranitidine, levocetirizine and motelukast. After 5 days of discharge lesions increased in both the lower limbs and upper limbs, for which he admitted to dermatology department of our hospital. A diagnosis of bullous pemphigoid was made based on clinical findings. Causation by drug was suspected and furosemide was removed from therapy and treated with prednisolone, halobetasol and antibiotics. The lesions improved significantly with the above management and patient recovered enough to be discharged from the hospital after 5 days. ADR causality assessment done with Naranjo's scale shown this ADR as probable (Table 1) and WHO scale shown it as probable/likely (Table 2).

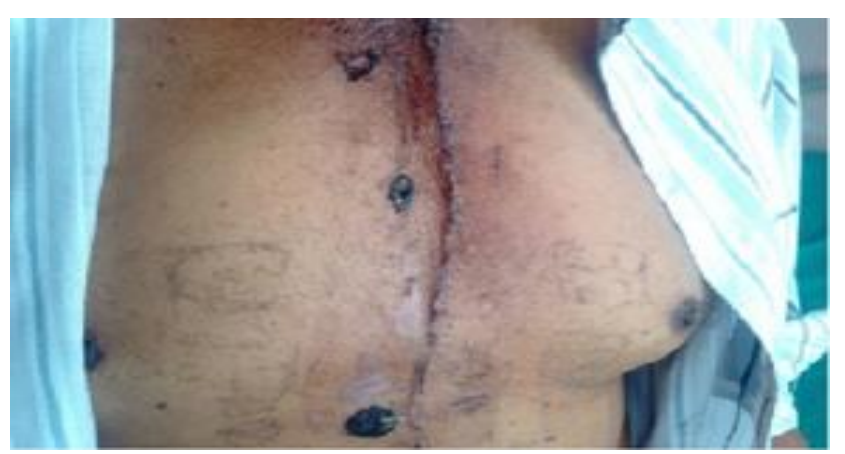

Figure 3: Collapsed bullae over the chest.

Table 1 : ADR Causality assessment (Naranjo scale). ${ }^{5}$

\begin{tabular}{|c|c|c|c|c|}
\hline Question & Yes & No & Do Not Know & Score \\
\hline 1. Are there previous conclusive reports on this reaction? & +1 & 0 & 0 & 1 \\
\hline $\begin{array}{l}\text { 2. Did the adverse event appear after the suspected drug was } \\
\text { administered? }\end{array}$ & +2 & -1 & 0 & 2 \\
\hline $\begin{array}{l}\text { 3. Did the adverse reaction improve when the drug was } \\
\text { discontinued or a specific antagonist was administered? }\end{array}$ & +1 & 0 & 0 & 1 \\
\hline $\begin{array}{l}\text { 4. Did the adverse event reappear when the drug was re- } \\
\text { administered? }\end{array}$ & +2 & -1 & 0 & $\mathbf{0}$ \\
\hline $\begin{array}{l}\text { 5. Are there alternative causes (other than the drug) that could on } \\
\text { their own have caused the reaction? }\end{array}$ & -1 & +2 & 0 & $\mathbf{0}$ \\
\hline 6. Did the reaction reappear when a placebo was given? & -1 & +1 & 0 & $\mathbf{0}$ \\
\hline $\begin{array}{l}\text { 7. Was the drug detected in blood (or other fluids) in concentrations } \\
\text { known to be toxic? }\end{array}$ & +1 & 0 & 0 & $\mathbf{0}$ \\
\hline $\begin{array}{l}\text { 8. Was the reaction more severe when the dose was increased or } \\
\text { less severe when the dose was decreased? }\end{array}$ & +1 & 0 & 0 & $\mathbf{0}$ \\
\hline $\begin{array}{l}\text { 9. Did the patient have a similar reaction to the same or similar } \\
\text { drugs in any previous exposure? }\end{array}$ & +1 & 0 & 0 & $\mathbf{0}$ \\
\hline 10. Was the adverse event confirmed by any objective evidence? & +1 & 0 & 0 & 1 \\
\hline Total & & & & 5 \\
\hline
\end{tabular}

Score: $\geq 9=$ definite ADR; 5-8=probable ADR; 1-4=possible ADR; $0=$ doubtful AD 
Table 2: WHO-UMC Causality assessment. ${ }^{5}$

\begin{tabular}{|c|c|}
\hline Causality term & Assessment criteria* \\
\hline \multirow{5}{*}{ Certain } & Event or laboratory test abnormality, with plausible time relationship to drug intake \\
\hline & Cannot be explained by disease or other drugs \\
\hline & Response to withdrawal plausible (pharmacologically, pathologically; \\
\hline & $\begin{array}{l}\text { Event definitive pharmacologically or phenomenologically (i.e. an objective and specific medical } \\
\text { disorder or a recognized pharmacological phenomenon) }\end{array}$ \\
\hline & Rechallenge satisfactory, if necessary \\
\hline \multirow{4}{*}{ Probable / Likely } & Event or laboratory test abnormality, with reasonable time relationship to drug intake \\
\hline & Unlikely to be attributed to disease or other drugs \\
\hline & Response to withdrawal clinically reasonable \\
\hline & Rechallenge not required \\
\hline \multirow{3}{*}{ Possible } & Event or laboratory test abnormality, with reasonable time relationship to drug intake \\
\hline & Could also be explained by disease or other drugs \\
\hline & Information on drug withdrawal may be lacking or unclear \\
\hline \multirow[t]{2}{*}{ Unlikely } & $\begin{array}{l}\text { Event or laboratory test abnormality, with a time to drug intake that makes a relationship improbable } \\
\text { (but not impossible) }\end{array}$ \\
\hline & Disease or other drugs provide plausible explanations \\
\hline \multirow{3}{*}{$\begin{array}{l}\text { Conditional / } \\
\text { Unclassified }\end{array}$} & Event or laboratory test abnormality \\
\hline & More data for proper assessment needed, or \\
\hline & Additional data under examination \\
\hline \multirow{3}{*}{$\begin{array}{l}\text { Unassessable / } \\
\text { Unclassifiable }\end{array}$} & Report suggesting an adverse reaction \\
\hline & Cannot be judged because information is insufficient or contradictory \\
\hline & Data cannot be supplemented or verified \\
\hline
\end{tabular}

* All points should be reasonable complied with

Table 3: Hartwig's severity assessment scale. ${ }^{6}$

\begin{tabular}{|ll|}
\hline Level 1 & $\begin{array}{l}\text { Assessment criteria } \\
\text { An ADR occurred but required no change in treatment with the suspected drug }\end{array}$ \\
\hline Level 2 & $\begin{array}{l}\text { The ADR required that treatment with the suspected drug be held, discontinued, or otherwise changed. No } \\
\text { antidote or other treatment requirement was required. No increase in length of stay (LOS). }\end{array}$ \\
\hline Level 3 & $\begin{array}{l}\text { The ADR required that treatment with the suspected drug be held, discontinued, or otherwise changed. } \\
\text { AND/OR an Antidote or other treatment was required. No increase in length of stay (LOS). }\end{array}$ \\
\hline Level 4 & $\begin{array}{l}\text { Any level } 3 \text { ADR which increases length of stay by at least } 1 \text { day (OR) The ADR was the reason for } \\
\text { admission. }\end{array}$ \\
\hline Level 5 & \begin{tabular}{l} 
Any level 4 ADR which requires intensive medical care. \\
\hline Level 6
\end{tabular} \\
\hline The adverse reaction caused permanent harm to the patient. \\
\hline Mild=level 1 and 2; Moderate=level 3 and 4; Severe=5, 6 and 7.
\end{tabular}

Table 4: ADR preventability assessment (Schumock and Thornton Preventability Scale).

\begin{tabular}{|c|c|}
\hline As: & ssment criteria \\
\hline De & nitely preventable \\
\hline 1 & Was there a history of allergy or previous reactions to the drug?- YES \\
\hline 2 & Was the drug involved inappropriate for the patient's clinical condition? \\
\hline 3 & Was the dose, route or frequency of administration inappropriate for the patient's age, weight or disease state? \\
\hline 4 & Was a toxic serum drug concentration (or laboratory monitoring test) documented? \\
\hline 5 & Was there a known treatment for the adverse drug reaction? \\
\hline $\operatorname{Pr}$ & ably preventable \\
\hline 6 & Was required therapeutic drug monitoring or other necessary laboratory tests not performed? \\
\hline 7 & Was a drug interaction involved in the ADR? \\
\hline 8 & Was poor compliance involved in the ADR? \\
\hline 9 & Were preventative measures not prescribed or administered to the patient? \\
\hline No & preventable \\
\hline 10 & If all above criteria not fulfilled \\
\hline
\end{tabular}


Severity was moderate according to Hartwig's severity assessment scale (Table 3). ADR preventability assessment with Schumock and Thornton Preventability Scale shows it was probably preventable (Table 4). All the above assessments are summarized as analysis of ADR and depicted in (Table 5).

Table 5: Analysis of the ADR.

\begin{tabular}{|ll|}
\hline Type & Results obtained \\
\hline Causality- Naranjo & Probable \\
\hline Causality- WHO-UMC & Probable/likely \\
\hline Severity- Hartwig & Moderate \\
\hline $\begin{array}{l}\text { Preventability- Schumock } \\
\text { and Thornton }\end{array}$ & Probably preventable \\
\hline
\end{tabular}

\section{DISCUSSION}

Bullous pemphigoid is one of the serious adverse drug reaction that leads to mortality and morbidity in elder patients, if timely care not taken. In our case the drug Furosemide injected as a routine medication for his cardiac manifestations along with other drugs such as betablockers (bisoprolol), NSAIDs (aspirin), which also known to cause DIBP. But the later two drugs were previously given in patient as elicited by history for his hypertension and ischemic heart disease and the duration of onset of reaction from the time of administration of furosemide was relatable. A UK case control study shown that diuretics and neuroleptics are more commonly associated drugs with DIBP. ${ }^{7}$ Another UK case control study stated that loop diuretics are the most frequent cause of DIBP. ${ }^{8}$ Several case reports before has shown the role of furosemide in DIBP in the past, but the events keep on repeating most probably due to decreased awareness of possibility of ADR in different population. ${ }^{4,9}$ One of the study done in tertiary care hospital in Karachi by Ahmed B et al shown that polypharmacy is the one of the main cause of drug induced adverse drug reactions. ${ }^{10}$ The concern on individual treatment and monitoring of drug reaction when a patient is on poly-pharmacy in specific population to be addressed to prevent this kind of reactions in future.

\section{CONCLUSION}

Serious reactions such as bullous pemphigoid can be caused by commonly used drug like furosemide. Proper history taking and tailoring treatment for individual, early detection and treatment of ADR is needed in such cases.
Funding: No funding sources

Conflict of interest: None declared

Ethical approval: Not required

\section{REFERENCES}

1. Lee JJ. Furosemide-induced bullous pemphigoid: case report and review of literature. $J$ drugs in dermatol: JDD. 2006 Jun;5(6):562-4.

2. Stavropoulos PG, Soura E, Antoniou C. Drug-induced pemphigoid: a review of the literature. J Eur Acad Dermatol Venereol. 2014;28(9):1133-40.

3. Agrawal J, Shenai KP, Chandra J, Veena KM, Chatra L. Drug-Induced Bullous Pemphigoid: Expect the Unexpected. World J Dentistry. 2011 AprilJune;2(2):151-3.

4. Helm MF, Lin L, Santalucia P, Brummitte Dale Wilson MD, Grover R. Furosemide Induced Bullous Pemphigoid Associated with Antihistone Antibodies. North Ame J Med and Sci. 2014 Jul 31;7(2):84-6.

5. Petrova G, Stoimenova A, Dimitrova M, Kamusheva M, Petrova D, Georgiev O. Assessment of the expectancy, seriousness and severity of adverse drug reactions reported for chronic obstructive pulmonary disease therapy. SAGE Open Med. 2017 Jan 31;5:2050312117690404.

6. Zaki SA. Adverse drug reaction and causality assessment scales. Lung India. 2011;28(2):152-153.

7. Bastuji-Garin S, Joly P, Picard-Dahan C, Bernard P, Vaillant L, Pauwels C, et al. Drugs associated with bullous pemphigoid: a case-control study. Arch dermatol. 1996 Mar 1;132(3):272-6.

8. Lloyd-Lavery A, Chi CC, Wojnarowska F, Taghipour $\mathrm{K}$. The associations between bullous pemphigoid and drug use: a UK case-control study. JAMA dermatol. 2013 Jan 1;149(1):58-62.

9. Takeichi S, Kubo Y, Arase S, Hashimoto T, Ansai SI. Brunsting-Perry type localized bullous pemphigoid possibly induced by furosemide administration and sun exposure. European J Dermatol. 2009 Sep 1;19(5):500-3.

10. Ahmed B, Nanji K, Mujeeb R, Patel MJ. Effects of polypharmacy on adverse drug reactions among geriatric outpatients at a tertiary care hospital in Karachi: a prospective cohort study. PLoS One. 2014 Nov 17;9(11):e112133.

Cite this article as: Venu D, Vijendra R. Furosemide induced bullous pemphigoid: a case report. Int J Basic Clin Pharmacol 2019;8:1444-7. 